\title{
Persentase Edible Offal Babi Nias Jantan Pada Berbagai Umur Ternak
}

\author{
Salam N. Aritonang \\ Fakultas Peternakan Universitas Andalas, Padang
}

\begin{abstract}
The research of edible offal percentage of male Nias pig in several animal ages has been carried out on ninety male Nias pig, which consisted of five aged group: $A(<269$ days old), $B$ (270-298 days old), $C$ (299-327 days old), D (328-356 days old) and $E(\geq 357$ days old). The research wad done by measuring of body and edible offal weight, edible offal percentage through out in the slaughter house in Gunungsitoli Nias. The relationship between animal age and each parameter measured were calculated by using regression analysis. The result of research indicated that there was a close relationship between animal age with their edible offal percentage. Increase of pig age were followed by decreasing of offal percentage with correlation coefficients of 0.896 .
\end{abstract}

Key words : Nias pig, edible offal

\section{Pendahuluan}

Babi merupakan salah satu komoditi ternak yang memiliki kontribusi yang sangat nyata dalam usaha memenuhi kebutuhan nasional akan daging sebagai sumber protein hewani, maupun untuk diekspor ke luar negeri. Namun kenyataannya populasi ternak babi di Indonesia masih terbatas dan belum dapat memenuhi kebutuhan konsumsi dalam negeri. Hal ini disebabkan oleh karena kondisi sosial budaya di Indonesia, di mana sebagian besar masyarakat Indonesia tidak mengkonsumsi daging babi.

Dilihat dari segi ekonomis ternak babi mempunyai kelebihan dibanding ternak lainnya, yaitu mampu melahirkan anak dua kali per tahun atau lima kali per dua tahun, dengan jumlah anak yang dilahirkan bisa mencapai 8 ekor/induk/kelahiran (Eusebio, 1980). Di samping itu dalam pemeliharaannya ternak babi lebih effisien karena dapat memanfaatkan sisa - sisa bahan makanan, baik sisa sisa dapur maupun sisa - sisa hasil pertanian.

Babi Nias merupakan salah satu jenis babi asli yang ada di Indonesia dan hidup di Pulau Nias. Babi ini termasuk tipe daging dengan bentuk badan berukuran sedang, bentuk kepala agak pendek, telinga kecil dan berdiri tegak, serta mempunyai bulu tebal terutama bagian leher dan pundak. Pada pemeliharaan secara tradisional sekalipun dapat mencapai berat badan $70 \mathrm{~kg}$ dalam umur 10 bulan (Sihombing, 1977).

Karkas babi merupakan berat seekor babi yang telah dipotong setelah dikurangi atau dipisahkan bagian kepala, paru - paru, jantung, jeroan dan ke empat kaki, sedangkan kulit, ginjal, ovarium, ekor dan leher merupakan bagian dari karkas (Goodwin, 1973). Adapun di luar karkas yang disebut non karkas (by product) menurut Eusebio (1980) 
terdiri dari edible offal (Non karkas yang dapat dimakan seperti jantung, hati, lidah dan saluran pencernaan dan kadang - kadang testikel, limpa, paru - paru, uterus dan darah) dan in-edible offal terdiri dari gigi, tulang, kaki, rambut/bulu, kelenjar dan hasil ikutan.

Umur ternak berpengaruh terhadap bentuk tubuh ternak, di mana pada umur yang lebih tinggi menghasilkan kualitas karkas yang rendah (Ensminger, 1991). Ternak babi yang dipotong pada fase pertumbuhan dan komponen fisik karkasnya telah optimum, bobot karkas yang dihasilkan juga akan meningkat sehub dengan meningkatnya bobot hidup, yang juga akan berpengaruh terhadap produksi edible offal yang dihasilkan (Siagian, 1999).

\section{Materi Dan Metode}

Penelitian ini menggunakan 90 ekor babi Nias jantan dari berbagai umur yang dikelompokkan dalam 5 kelompok umur yaitu A (<269 hari), B (270 - 298 hari), C (299 - 327 hari), D (328 - 356 hari) dan $E(\geq 357$ hari). Metode penelitian yang digunakan adalah metode survey dengan melakukan pengukuran langsung terhadap peubah yang diamati, yaitu berat hidup, berat edible offal (jantung, hati, saluran pencernaan, lidah, limpa) dan persentase edible offal babi Nias jantan di Rumah Potong Hewan Gunungsitoli Nias. Untuk mengetahui hubungan antara umur ternak dengan masing - masing peubah dilakukan dengan menggunakan analisis regresi.

\section{HASIL DAN PEMBAHASAN}

\section{Berat Hidup Berdasarkan Umur}

Bertambahnya umur telah meningkatkan berat hidup babi Nias jantan, di mana pada kelompok E yaitu umur $\geq 357$ hari atau lebih $(\geq$ 11,9 bulan) rata - rata berat hidup yang dicapai paling tinggi sekitar 99,7 kg. Berat hidup tersebut jika dibandingkan dengan hasil penelitian Sihombing (1997) pada kisaran berat yang sama dengan $90-100 \mathrm{~kg}$ dapat dicapai pada umur yang lebih muda yaitu umur $32-40$ minggu $(8-10$ bulan). Hal ini disebabkan babi Nias termasuk babi tipe kecil sehingga pertumbuhannya lambat, di mana pada umur yang sama berat hidup yang dicapai jauh lebih rendah.

Hasil analisis regresi menunjukkan, bahwa umur memiliki hubungan yang sangat erat $(P<0,01)$ dengan berat hidup babi Nias jantan dengan persamaan regresi $\mathrm{Y}=-6,456$ $+0,276 \mathrm{X}$, dan koefisien korelasi 0,961 . Ini berarti bahwa berat hidup babi Nias jantan $96,1 \%$ sangat dipengaruhi oleh umur.

\section{Berat Edible Offal Berdasarkan Umur}

Bertambahnya umur dapat meningkatkan berat edible offal babi Nias jantan, di mana pada kelompok $\mathrm{E}$ yaitu umur $\geq 357$ hari rata - rata berat edible offal yang dicapai paling tinggi yaitu $24,9 \mathrm{~kg}$. Sesuai dengan pendapat Forrest dkk. (2000), bahwa dengan bertambahnya umur maka pertumbuhan dan perkembangan organ organ tubuh ternak, baik komponen karkas maupun non karkas, termasuk dalam hal ini edible offal mengalami peningkatan.

Hasil analisis regresi menunjukkan, bahwa umur memiliki hubungan yang sangat erat $(\mathrm{P}<0,01)$ dengan berat edible offal babi Nias jantan. Persamaan regresi yang diperoleh adalah $\mathrm{Y}=5,862-0,0511 \mathrm{X}$ dengan koeffisien korelasi 0,882 . Ini berarti berat edible offal babi Nias jantan 88,2 $\%$ dipengaruhi oleh umur. 
Persentase Edible Offal Berdasarkan Umur

Bertambahnya umur telah menurunkan persentase edible offal babi Nias jantan, di mana pada kelompok E yaitu umur $\geq 357$ hari rata-rata persentase edible offal yang dicapai paling rendah, yaitu $24,57 \%$. Jika dihubungkan dengan berat hidup babi Nias jantan hasil penelitian ini menunjukkan, bahwa semakin bertambahnya umur maka akan diikuti oleh meningkatnya berat hidup namun menurunkan persentase edible offal yang dihasilkan. Sesuai dengan pendapat Ensminger (1991) bahwa dengan bertambahnya umur maka bertambah pula berat badan ternak, yang diikuti juga oleh menurunnya persentase edible offal babi Nias jantan yang diperoleh dengan membandingkan berat edible offal dengan berat hidup babi Nias jantan.

Hasil analisis regresi menunjukkan, bahwa umur memiliki hubungan yang sangat erat $(\mathrm{P}<0,01)$ dengan persentase edible offal babi Nias jantan dengan persamaan regresi $\mathrm{Y}=$ $11,316+0,24 \mathrm{X}$ dan koeffisien korelasi 0,896 . Ini berarti bahwa persentase edible offal $89,6 \%$ dipengaruhi oleh umur.

\section{Kesimpulan}

Umur mempunyai hubungan yang sangat erat dengan persentase edible offal babi Nias jantan, di mana dengan bertambahnya umur akan menurunkan persentase edible offal dengan koeffisien korelasi 0,896 .

\section{Daftar Pustaka}

Ensminger, M.E. 1991. Animal Science. $5^{\text {th }}$ Ed. The Interstate Printed and Publisher Inc. Denville Illinois.

Eusebio, J.A. 1980. Pig Production in The Tropics. Longman Group Ltd. Essex.

Forrest, C.J., D.A. Elton., B.A. Harold and A.M. Robert. (2000). Principle of Meat

Science. W.H. Freeman and Co. San Fransisco.

Goodwin, D.H. 1973. Pig Managemen and Production. Hutchinson Education.

Sihombing, D.T.H. 1997. Ilmu Beternak Babi. Gajah Mada University Press. Yogyakarta.

Tabel 1. Rangkuman Hasil Penelitian Persentase Edible Offal Babi Nias Jantan Pada Berbagai Umur Ternak.

\begin{tabular}{cccc}
\hline $\begin{array}{c}\text { Kelompok Umur } \\
\text { (hari) }\end{array}$ & $\begin{array}{c}\text { BeratHidup } \\
(\mathrm{kg})\end{array}$ & $\begin{array}{c}\text { Berat Edible Offal } \\
(\mathrm{kg})\end{array}$ & $\begin{array}{c}\text { Persentase Edible } \\
\text { Offal (\%) }\end{array}$ \\
\hline$<269$ & 54,82 & 16,59 & 30,16 \\
$270-298$ & 71,50 & 20,60 & 28,61 \\
$299-327$ & 82,40 & 23,10 & 28,08 \\
$328-356$ & 92,60 & 24,35 & 26,16 \\
$\geq 357$ & 99,70 & 24,90 & 24,57 \\
\hline Koef. Korelasi & 0,961 & 0,882 & 0,896 \\
\hline
\end{tabular}

Alamat Korespondensi: Dr. Ir. Salam N. Aritonang Jl. Kis Mangunsarkoro 11 Padang. 25129 HP.08126701553 